MUHASEBE VE FINANS INCELEMELERI DERGISI

Journal Webpage: www.dergipark.gov.tr/mufider

\title{
THE IMPACT OF COVID-19 CORONAVIRUS ON STOCK MARKETS: EVIDENCE FROM SELECTED COUNTRIES
}

\section{KOVID-19 KORONAVIR ÜS ÜN HISSE SENEDİ PIYYSALARINA ETKISSI: SEÇILMIŞ ÜLKELERDEN KANITLAR}

\section{Feyyaz ZEREN ${ }^{\text {a* Atike Elanur HIZARCI }}{ }^{b}$}

a* Corresponding Author, Assoc. Prof. Dr., Yalova University, Faculty of Economics and Administrative Sciences, Department of International Trade and Finance, feyyaz.zeren@yalova.edu.tr , ORCID: 0000-00020024-3518

$b$ Ress. Assist., Yalova University, Faculty of Economics and Administrative Sciences, Department of International Trade and Finance, atike.hizarci@yalova.edu.tr, ORCID: 0000-0003-0575-0460

\section{ARTICLE INFO}

Article history:

Received: 19.03.2020

Revised: 21.03 .2020

Accepted: 26.03 .2020

Keywords: Covid-19

Coronavirus, Stock Markets,

Epidemic, Death, Case

Jel Codes: D53, I15

\section{RESEARCH ARTICLE}

BENZERLİK/ PLAGIARISM

Ithenticate: \%9

\section{MAKALE BİLGÍLERİ}

\section{Makale Tarihçesi:}

Gönderilme Tarihi: 19.03.2020

Düzenleme Tarihi: 21.03.2020

Kabul Tarihi: 26.03.2020

Anahtar Sözcükler: Kovid-19

Koronavirüs, Borsa, Salgın,

Ölüm, Vaka

Jel Kodlart: D53, I15

\begin{abstract}
In this paper, it has been aimed to reveal the possible effects of Covid-19 Coronavirus epidemic on stock markets. In the analysis using daily data between 23 January 2020 and 13 March 2020, possible effects on stock markets has been investigated with Maki (2012) cointegration test using both Covid-19 daily total death and Covid-19 daily total case. According to the results obtained, all stock markets examined with total death act together in the long run. It has been understood that total cases have cointegration relationship of SSE, KOSPI and IBEX35 and do not have cointegration relationship with FTSE MIB, CAC4O, $D A X 30$. In this regard, it is considered as one of the optimal option for investors to avoid investments in stock markets, turn to investment in gold markets, which is the safe investment port of each crisis period in long run. Also, considering the possibility of turning all life into an internet environment, turning to cryptocurrencies is seen as another alternative option for investors. In this direction, it will be the preference of investors to turn to derivative markets and to the stock markets of countries where Covid-19 is relatively rare to avoid risk.
\end{abstract}

\section{ÖZET}

Bu çalışmada, Kovid-19 Koronavirüs salgınının borsalar üzerindeki olası etkilerini ortaya koymak amaçlanmıştır. 23 Ocak 2020 ve 13 Mart 2020 arasındaki günlük veriler kullanılarak yapılan analizlerde, hem Covid-19 günlük toplam ölüm hem de Covid-19 günlük toplam vaka sayllarının, Maki (2012) eşbütünleşme testi kullanılarak borsalar üzerindeki olası etkileri araştırılmıştır. Elde edilen sonuçlara göre, toplam ölümle incelenen tüm borsalar uzun vadede birlikte hareket etmektedir. Toplam vakaların SSE, KOSPI ve IBEX35 ile eşbütünleşme ilişkisi içerisinde olduğu ve bu vakaların FTSE MIB, CAC40, DAX30 ile eşbütünleşik olmadı̆̆ anlaşılmıştır. Bu bağlamda, yatırımcıların 
borsa yatırımlarından kaçınmaları, her kriz döneminin güvenli limanı olan altın piyasalarına yönelmeleri uzun vadede en uygun seçeneklerden biri olarak görülmektedir. Ayrıca, tüm hayatın bir internet ortamına dönüşme olasılı̆̆ göz önüne alındığında, sanal para birimlerine yönelmek yatırımcılar için bir başka alternatif seçenek olarak görülmektedir. Yine bu doğrultuda riskten kaçınmak için yatırımclların türev piyasalara ve Covid-19'un nispeten nadir görüldüğ̈̈ ülkelerin hisse senedi piyasalarına yönelmesi önerilmektedir.

\section{INTRODUCTION}

History has witnessed many epidemic diseases that have caused many deaths to date. The Black Death "Plague Outbreak" that led to the deaths of 75-100 million people between 1347 and 1351, the Bleeding Fever that occurred in Mexico in 15451548, the Cholera epidemic between 1899 and 1923, the AIDS virus that first appeared in Cameroon in 1908, severe acute respiratory syndrome (SARS) that were effective in Asia and Canada between 2002 and 2003, Ebola and Swine Flu are some of them.

Covid-19 Coronavirus (2019-nCoV) is a type of outbreak that first appeared in December 2019 in Wuhan City, Hubei Province, China (Estrada et. al., 2020). It has been declared as a pandemic by the World Health Organization (WHO) on March 12, 2020. As of March 26, 2020, due to this epidemic the deaths have exceeded 22.000, which has continued to affect the whole world. In addition to China, there have been serious increases in the number of cases and death, especially in Italy and Iran. These developments started to affect social and cultural activities all over the world. Due to the virus, international flights between many countries have been canceled, and border crossings with risky countries have been closed. State of Emergency has been declared in some countries. Interrupting education for a certain period of time or switching to the online course system is another example of how Covid-19 affects life, especially in China, Japan, France, Iran, Italy, Turkey and many countries. Also, it has been announced that organizations or congress with high participation have been postponed or canceled in many countries. Furthermore, being the Italian Football League Serie-A, football leagues have been delayed in many European countries or it has been decided to play matches without spectators. The postponement of the Olympic games planned to be held in japan in the summer of 2020 still maintains its place on the agenda as of the date of the study (Ayittey et. al., 2020).

The Covid-19 epidemic negatively affects global trade as well as social and cultural life. Especially tourism, trade in commodities, production and transportation sectors have started to be negatively affected by this epidemic. Accordingly, Moody's and Standard \& Poors credit rating agencies have lowered China's growth forecast for 2020. General Motors, Nissan, Renault and Peugeot, Honda and Toyota decided to stop production in China. Many countries that import goods from China or have their goods manufactured in China have decided to stop these activities. In line with all these negative effects, it seems inevitable that stock markets, economic growth and exchange rates will also have a share in these situations. Accordingly, the study aimed to investigate the relationship between Covid19 and stock markets in China, South Korea, Italy, France, Germany and Spain, where this virus is most effectively seen. These relationships have been examined with Maki (2012) cointegration tests.

When the studies in the literature are examined, many studies investigating the relationship between epidemics and economic developments have been found. One of the oldest studies encountered in this direction belongs to Yang et.al. (1999). In this work, the authors tried to calculate the financial cost of 1997 foot-and-mouth disease in Taiwan. Carpernter (2011) analyzed the impact of the same outbreak on economic growth for California and according to the obtained results, it has been understood that the mentioned epidemic had an effect on the city economy. Similar to Yang et.al. (2008), Armien and Halasa (2012) tried to calculate the financial cost of the dengue outbreak that occurred in Panama and Puerto Rico, respectively.

In the study of Bloom and Mahal (1997), the relationships between AIDS and economic growth have been examined. According to the results, AIDS and economic growth have a cointegrated long-term structure. However, there was no evidence of causality between the two variables. In a similar study, Barnett et. al. (2000) analyzed the relation between AIDS and GDP. They found a negative relationship between them in Ukraine. In another study, Vijayakumar et.al. (2013) examined the relationship between chikungunya epidemic emerging in India and per-capita monthly income and found that there was no relationship between these two variables. 
In addition to the epidemics listed so far, SARS is the most investigated epidemic in the literature. Gupta (2005) analyzed the economic effects of quarantine in Toronto, Chen et.al (2007) investigated the effects of SARS on Taiwan hotel stock performance and Beutels et. al. (2009) examined the Chinese economy, all of them determined the negative effects of the SARS outbreak on these variables.

As of the date of this study, there is no study investigating the relationship between Covid-19 and economic variables, but there are three studies, Ayittey et.al. (2020), Luo and Tsang (2020), Estrada et.al. (2020), who try to interpret the possible effects of the current state of the virus on the economy. With this research, it has been tried to be revealed as the first study to reveal the relationship between Covid19 and stock markets with empirical findings by using time series analysis and this reveals the original side of the work. In the following sections of the study, the econometric method, the data and empirical findings, the conclusion section where these findings are discussed and suggestions for future studies are presented.

\section{ECONOMETRIC METHOD}

A time series is stationary, if it has a constant mean, a constant variance, and a constant covariance. In this context, the fact that the time series is approaching a certain value over time, namely it is stationary, indicates that it has a non-random structure (Gujarati, 2011: 718). When the applications in the literature are examined, it is possible to mention many unit root tests such that traditional ADF, PP and KPSS unit root tests that do not consider structural breaks, Zivot Andrews (1992) should be a structural break, Lee Strazicich $(2003,2012)$ developed two structural breaks, and Carrion-i Sylvestre (2009) developed multiple structural break unit root tests. In addition, it should be mentioned that Fourier ADF and Fourier KPSS unit root tests, which take into account a large number of smooth transition structural breaks, have been brought into the literature.

All of the tests mentioned up to now accept that the variance of error terms is fixed. However, the RALS-LM unit root test, which is recently introduced into the literature and used in this study, solves the problem of volatility in error terms by using $G$ / $\operatorname{ARCH}(p, q)$ models that use the square of the past values of the error term (Çoban et. al, 2018, 326).
The RALS-LM test developed by Meng et. al. (2014) is a method that both provides solutions to the normal distribution problem of errors and allows 1 and 2 structural breaks. In addition to the original articles of the authors who developed the method to obtain more detailed econometric information about that, the articles of Özcan and Erdoğan (2015) and Dursun (2018) can be examined.

In study of Maki in 2012, criticized one break Gregory-Hansen (1996) and two breaks Hatemi-J tests (2008), and put forward the cointegration test in which the number of structural breaks has been determined internally. According to this model, the basic hypothesis is that there is no cointegration relationship between the variables, while the alternative hypothesis is that there is a cointegration relationship that considers the number of structural breaks determined by the model. Four models are presented for this test and it is stated that one of them will be selected:

$$
\begin{aligned}
& y_{t}=\mu+\sum_{i=1}^{k} \mu_{i} D_{i, t}+\beta^{\prime} x_{t}+u_{t} \\
& y_{t}=\mu+\sum_{i=1}^{k} \mu_{i} D_{i, t}+\beta^{\prime} x_{t}+\sum_{i=1}^{k} \beta^{\prime} x_{t} D_{i, t}+u_{t} \\
& y_{t}=\mu+\sum_{i=1}^{k} \mu_{i} D_{i, t}+\gamma t+\beta^{\prime} x_{t} \sum_{i=1}^{k} \beta^{\prime} x_{t} D_{i, t}+u_{t} \\
& y_{t}=\mu+\sum_{i=1}^{k} \mu_{i} D_{i, t}+\gamma t+\sum \gamma_{i} t D_{i, t}+\beta^{\prime} x_{t}+ \\
& \sum_{i=1}^{k} \beta^{\prime} x_{t} D_{i, t}+u_{t}
\end{aligned}
$$

In this study, model number 4 , which allows changes in level, trend and independent variables due to the structure of the series, has been discussed. In the process of the Maki cointegration test, the selected model is estimated for each possible structural break and the unit root test statistics applied to the residuals are obtained. Then, the model with the least total residual squares in the selected models is determined as the first break point. After the first structural break is included in the selected model, the investigation continues until the number of upper breaks permitted by the researcher who applied this way for the second, third and other structural breaks. Among the estimated models, the number of breaks with the test statistic, which gives the smallest $\mathrm{T}$ statistics, is selected as the appropriate break number (Y1lanc1, 2013).

\section{DATA AND EMPIRICAL FINDINGS}

In this study, data related to China, South Korea, Italy, France, Germany and Spain, where 
Covid-19 virus is most common countries, have been used to perform econometric analysis. Also, Iran is one of the countries where the Covid-19 spreads rapidly, but stock market indices data has not been reached and has been excluded from study. As of the data range, the Covid-19 Death emerged on 23 January 2020 and the end date has been determined as 13 March 2020. The data has been used at the daily frequency. The deaths and cases related to the Covid19 and the daily stock market indices data has been obtained from the website www.worldometers.info and at www.uk.finance.yahoo.com, respectively.

In the econometric application part of the study, Maki Cointegration test (2012) will be used to determine whether there is a long-term relationship between the variables, and the stationary levels of the series should be determined to test this relationship. For this reason, the RALS-LM unit root test developed by Meng et. al. (2014), which allows multiple structural breaks, has been used. The results obtained from this test are presented in Table 1.

Table 1: RALS-LM Two Structural Breaks Unit Root Test Results

\begin{tabular}{|c|c|c|c|c|c|}
\hline & \multicolumn{2}{|c|}{$\mathbf{T}_{\text {RALS-LM }}$} & \multicolumn{2}{c|}{$\begin{array}{c}\mathbf{p}^{2} \text { for } \\
\text { level }\end{array}$} & \multicolumn{2}{c|}{ Structural Break Dates in level } \\
\cline { 2 - 5 } & Level & 1st Dif. & & \multicolumn{2}{c|}{} \\
\hline Covid-19 Daily Total Death & -1.630 & $-5.761 * * *$ & 0.954 & 03.03 .2020 & 05.03 .2020 \\
\hline Covid-19 Daily Total Case & -2.052 & $-8.408 * * *$ & 0.522 & 13.02 .2020 & 17.02 .2020 \\
\hline China (SSE) & -2.332 & $-9.841 * * *$ & 0.875 & 05.03 .2020 & 09.03 .2020 \\
\hline Italy (FTSE MIB) & -2.143 & $-5.314 * * *$ & 0.318 & 05.03 .2020 & 09.03 .2020 \\
\hline South Korea (KOSPI) & -3.445 & $-3.661 * *$ & 0.06 & 28.01 .2020 & 05.02 .2020 \\
\hline France (CAC40) & -1.67 & $-6.632 * * *$ & 0.167 & 03.03 .2020 & 05.03 .2020 \\
\hline Germany (DAX30) & -2.242 & $-6.151 * * *$ & 0.249 & 05.03 .2020 & 09.03 .2020 \\
\hline Spain (IBEX35) & -2.604 & $-5.904 * * *$ & 0.603 & 05.03 .2020 & 09.03 .2020 \\
\hline
\end{tabular}

Note: Critical Values "Meng, M., Lee, J. ve Payne, J. E. (2016). RALS-LM Unit Root Test with Trend Breaks and NonNormal Errors: Application to the Prebisch-Singer Hypothesis. In B. Mizrach (ed.), Studies in Nonlinear Dynamics \& Econometrics, 21(1), 31-45" are obtained in accordance with $p^{2}$ values from this article. ***, **, * indicates $1 \%, 5 \%$ and $10 \%$ significance level mean that the test statistic is meaningful, respectively.

Table 2: Maki Cointegration Test Results

\begin{tabular}{|c|c|c|c|}
\hline & T-statistics & Critical Values & Structural Break Dates \\
\hline $\begin{array}{c}\text { Covid-19 Daily Total Death } \\
\text { vs SSE }\end{array}$ & $-8.61^{* * *}$ & $-8.00,-7.41,-7.11$ & $\begin{array}{c}29.01 .2020,10.02 .2020,13.02 .2020, \\
18.02 .2020,26.02 .2020\end{array}$ \\
\hline $\begin{array}{c}\text { Covid-19 Daily Total Death } \\
\text { vs FTSE MIB }\end{array}$ & $-7.15^{* * *}$ & $-7.08,-6.52,-6.26$ & $04.02 .2020,21.02 .2020,05.03 .2020$ \\
\hline $\begin{array}{c}\text { Covid-19 Daily Total Death } \\
\text { vs KOSPI }\end{array}$ & $-8.27 * * *$ & $-6.04,-5.54,-5.28$ & 26.02 .2020 \\
\hline $\begin{array}{c}\text { Covid-19 Daily Total Death } \\
\text { vs CAC40 }\end{array}$ & $-6.18^{* * *}$ & $-6.04,-5.54,-5.28$ & 26.02 .2020 \\
\hline $\begin{array}{c}\text { Covid-19 Daily Total Death } \\
\text { vs DAX30 }\end{array}$ & $-7.47 * * *$ & $-6.62,-6.10,-5.84$ & $18.02 .2020,27.02 .2020$ \\
\hline $\begin{array}{c}\text { Covid-19 Daily Total Death } \\
\text { vs IBEX35 }\end{array}$ & $-6.60^{* * *}$ & $-6.04,-5.54,-5.28$ & 21.02 .2020 \\
\hline $\begin{array}{c}\text { Covid-19 Daily Total Case } \\
\text { vs SSE }\end{array}$ & $-9.21 * * *$ & $8.00,-7.41,-7.11$ & $\begin{array}{c}27.01 .2020,03.02 .2020,13.02 .2020, \\
18.02 .2020,21.02 .2020\end{array}$ \\
\hline $\begin{array}{c}\text { Covid-19 Daily Total Case } \\
\text { vs FTSE MIB }\end{array}$ & -5.57 & $-7.55,-7.00,-6.71$ & $\begin{array}{c}12.02 .2020,19.02 .2020,24.02 .2020, \\
10.02 .2020\end{array}$ \\
\hline $\begin{array}{c}\text { Covid-19 Daily Total Case } \\
\text { vs KOSPI }\end{array}$ & $-14.77 * * *$ & $-8.00,-7.41,-7.11$ & $\begin{array}{c}03.02 .2020,06.02 .2020,20.02 .2020, \\
27.02 .2020,10.03 .2020\end{array}$ \\
\hline $\begin{array}{c}\text { Covid-19 Daily Total Case } \\
\text { vs CAC40 }\end{array}$ & -6.64 & $-7.55,-7.00,-6.71$ & $\begin{array}{c}29.01 .2020,03.02 .2020,12.02 .2020, \\
02.03 .2020\end{array}$ \\
\hline $\begin{array}{c}\text { Covid-19 Daily Total Case } \\
\text { vs DAX30 }\end{array}$ & -5.82 & $-7.08,-6.52,-6.26$ & $06.02 .2020,21.02 .2020,03.03 .2020$ \\
\hline $\begin{array}{c}\text { Covid-19 Daily Total Case } \\
\text { vs IBEX35 }\end{array}$ & $-7.09 * * *$ & $-7.08,-6.52,-6.26$ & $03.02 .2020,12.02 .2020,09.03 .2020$ \\
\hline
\end{tabular}

Note: *** indicates $1 \%$ significance level mean that the test statistic is meaningful. Critical Values are taken from study named Maki, D. (2012) "Tests for cointegration allowing for an unknown number of breaks". 
When the RALS-LM test results developed by Meng et al. (2014) have been analyzed, it has been seen that both Covid-19 data and country stock market data had unit roots in level and became stationary as a result of the first difference. When the results obtained are examined thoroughly, it is seen that the structural break dates in the stock markets coincided with the beginning of March 2020, when the Covid-19 virus effect began to be felt seriously in Europe. There is a serious increase in the number of people who died from Covid-19 in these dates and this situation is seen in the results of analysis as structural break. It is considered appropriate to use Maki cointegration test, which takes into account multiple structural breaks in a situation where all series are stationary in the first differences. The results for this test are presented in Table 2.

When the Maki (2012) cointegration test results are examined, it is understood that each country stock market examined with Covid-19 daily total death has a cointegrated structure. On the other hand, it is understood that there is a long-term relationship between Covid-19 daily total case and Chinese stock market SSE, South Korean stock market KOSPI and Spain stock market IBEX35. However, no relation has been found between the daily total case and the Italian stock market FTSE MIB, the French stock market CAC40 and the German stock market DAX30. At this stage of the study, it is econometrically possible to reveal the direction of the cointegration relationship and even causality relationships between these variables. However, the ensuing of the cointegration relationship is based on the theoretical basis that the direction of this relationship is negative. For this reason, cointegration estimator calculation has not been required at this part of the study. As a result of the theoretical basis of the study, it is not required to apply causality tests since stock markets cannot be the cause of Covid-19.

\section{CONCLUSION REMARKS}

Covid-19 coronavirus, which appeared in China at the end of December 2019, has been declared as a pandemic by the World Health Organization (WHO) on March 12, 2020 after it spread to many countries. The effects of this virus, which affects the whole world, in both socio-cultural and commercial context have been inevitable. Sociocultural activities are almost entirely limited, country economies have been seriously affected by Covid-19, and sectors such as tourism, trade in commodities, production and transportation have faced serious problems.

In this study, it has been aimed to investigate the relations between Covid-19 daily total death and Covid-19 daily total cases with stock markets in China, South Korea, Italy, France, Germany and Spain where Covid-19 is widely seen. Accordingly, the cointegration test with multiple break developed by Maki (2012) has been used. While the existence of a cointegrated structure is detected between daily total death and all country stock markets, a relationship has been detected between daily total case and just some country stock markets. Accordingly, the occurrence of death affects all investors, whereas hearing the case, but the absence of death did not affect some of the stock markets of some countries. Considering that the stock markets of many countries do not act according to the efficient market hypothesis and tend towards the behavioral finance theories; it is understood that investors in the stock markets of Italy, France and Germany are not psychologically affected by the realization of the cases. It is seen in the results that the investors started to be affected by the deaths in these 3 countries.

Considering that the Covid-19 cases and deaths have increased day by day in line with the results obtained, it is understood that investing in in the stock market is not the right option for investors. Investing in gold markets, which is seen as a safe haven in all financial markets, can be seen as a logical choice for investors. With the increasing spread of Covid-19, all business life started to work on the internet and this process gradually can extend, cryptocurrencies such as Bitcoin, the most widely used cryptocurrencies in the world, can be seen as another financial instrument to invest. Also, in order to minimize the risk, turning to derivative products will also be one of the right options. Another right investment option in this extraordinary situation would be to turn to country markets, where Covid-19 cases are relatively low.

As a result, the serious economic losses faced due to the pandemic by countries such as China, Italy, France, and Germany indicate that with the end of Covid-19, the cards will be redistributed and the global trade will give new signals of move. The fact that it is one of the pioneering studies that reveals the relationship between Covid-19 case and stock markets with empirical findings reveals the original side of the paper. However, the fact that the study has 
been carried out with limited data does not provide clear findings about what results will occur in the future. The results to be obtained with a wider frequency of data will reveal the possible effects of the pandemic on financial markets and economy with clearer findings. However, the fact that macroeconomic variables such as GDP, Trade Openness, and Unemployment are not measured at daily frequencies, so does not yet enable an empirical study to reveal the relationship between these variables and Covid-19. In the event that the pandemic continues, future studies with a new model that will be created by taking these variables into account will present important economic findings to policy makers.

\section{REFERENCES}

Armien, B., Suaya, J. A., Quiroz, E., Sah, B. K., Bayard, V., Marchena, L. Campos, C. and Shepard, D. S. (2008). Clinical Characteristics and National Economic Cost of the 2005 Dengue Epidemic in Panama, Am. J. Trop. Med. Hyg., 79(3), 2008, 364-371.

Ayittey, F. K., Ayittey, M. K., Chiwero, N. B. Kamasah, J. S. and Dzuvor, C. (2020). Economic Impacts of Wuhan 2019-nCoV on China and the World, Journal of Medical Wirology, 1-3. 10.1002/jmv.25706

Barnetta, T., Whitesideb, A., Khodakevichc, L. Kruglovd, Y. and Steshenko, V. (2000). The HIV/AIDS Epidemic in Ukraine: Its Potential Social and Economic Impact, Social Science \& Medicine, 51, 1387-1403

Beutels, P., Jia, N. Zhou, Q., Smith, R., Cao, W. and Vlas, S. J. (2009). The Economic Impact of SARS in Beijing, China, Tropical Medicine and International Health, 14, 1, 85-91

Bloom, D. E. and Mahal, A. S. (1997). Does the AIDS Epidemic Threaten Economic Growth?, Journal of Econometrics, 77, 105-124

Carpenter, T. E. O'Brien, J. M. Hagerman, A. D. and McCarl, B. A. (2011). Epidemic and economic impacts of delayed detection of foot-and-mouth disease: a case study of a simulated outbreak in California, J Vet Diagn Invest, 23:26-33.

Carrion-i-Sylvestre J. L., Kim, D. and Perron P. (2009). GLS-Based Unit Root Tests with Multiple Structural Breaks Under Both the Null and the Alternative Hypotheses. Econometric Theory, 25, 1754-1792.
Chen, M. H., Jang, S. C. and Kim, W. G. (2007). The Impact of the SARS Outbreak on Taiwanese Hotel Stock Performance: An Event-Study Approach, Hospitality Management, 26, 200-212.

Çoban, B. Firuzan, E. and Oğuzhan, A. (2018). Farklı Varyanslık ve Yapısal Kirılmalar Altında Ekonomik Büyüme ile Turizm İlişkisinin İncelenmesi, Trakya Üniversitesi Sosyal Bilimler Dergisi, Haziran, 20, 1, 319-337.

Dursun, G. (2018). İşsizlik Histerisi İstihdam Histerisine Eşit Mi? Lm ve Yapısal Kırılmalı Rals-Lm Birim Kök Testlerinden Kanitlar, Current Debates in Economics, Current Debates, No. 18.

Estrada, M. A. R., Park, D., Koutronas, E., Khan, A. and Tahir, M. (2020). The Impact of Massive Infectious and Contagious Diseases and Its Impact on the Economic Performance: The Case of Wuhan, China, Social Science Research Network Report.

Gregory A. W. and Hansen B. E. (1996). Residual-Based Tests for Cointegration in Models with Regime Shifts. Journal of Economomics, 70, 99-126.

Gujarati, D. (2011). Temel Ekonometri, Çeviren: Ümit Şenesen, Gülay Günlük Şenesen, Literatür Yayıncılık.

Guptaa, A. G., Moyera, C. A. and Stern, D. T. (2005). The Economic Impact of Quarantine: SARS in Toronto as a Case Study, Journal of Infection, 50, 386-393

Halasa, Y. A., Shepard, D. S. and Zeng, W. (2012). Economic Cost of Dengue in Puerto Rico, Am. J. Trop. Med. Hyg., 86 (5), 745-752

Hatemi-J, A. N. (2008). Tests for Cointegration with Two Unknown Regime Shifts with an Application to Financial market Integration, Empirical Economics, 35, 497-505.

Lee, J. and Strazicich, M. C. (2003). Minimum LM Unit Root test with Two Structural Breaks. Review of Economics and Statistics, 85, 1082-1089. doi:10.1162/003465303772815961

Lee, J., Strazicich, M. C., and Meng, M. (2012). Two-step LM Unit Root Tests with Trend-Breaks. Journal of Statistical and Econometric Methods, 1, 81107.

Luo, S. and Tsang, K. P. (2020). How Much of China and World GDP Has The Coronavirus Reduced?, Social Science Research Network Report.

Maki D. (2012) Tests for Cointegration Allowing for an Unknown Number of Breaks, Economic Modelling, 29, 2011-2015. 
Meng, M. K. Im, J. Lee and Tieslau, M. (2014). More Powerful LM Unit Root Tests with Non-Normal Errors. The Festschrift in Honor of Peter Schmidt, edited by R. Sickles and W. Horrace, 343-357, Berlin, Germany: Springer Publishing Co.

Meng, M., Lee, J. and Payne, J. E. (2016). RALS-LM Unit Root Test with Trend Breaks and Non-Normal Errors: Application to the Prebisch-Singer Hypothesis. In B. Mizrach (ed.), Studies in Nonlinear Dynamics \& Econometrics, 21(1), 3145

Özcan, B. and Erdogan, S. (2015). Are Turkey's Tourism Markets Converging? Evidence from the TwoStep LM and three-step RALS-LM unit root tests, Current Issues in Tourism, 10.1080/13683500.2015.1040741

Vijayakumar, K., George, B. Anish, T. S. Rajasi, R. S., Teena, M. J. and Sujina, C. M. (2013). Economic Impact of Chikungunya Epidemic: Out-Of-Pocket Health Expenditures During The 2007 Outbreak In Kerala, India, Southeast Asian J Trop Med Public Health, 44, 1, 54-61

Yang, P. C., Chu, R. M., Chung, W. B. and Sung, H. T. (1999). Costs of the 1997 Foot-and-Mouth Disease Epidemic in Taiwan, Veterinary Record, 145, 731-734

Yang, H. Y. and Chen K. H. (2009). A General Equilibrium Analysis of the Economic Impact of a Tourism Crisis: a Case Study of the SARS Epidemic in Taiwan, Journal of Policy Research in Tourism, Leisure and Events, 1:1, 37-60, 10.1080/19407960902738313

Y1lanc1, V. (2013). Financial Econometrics Training given at Sakarya University on 1-5 June 2013.

Zivot, Eric and Andrews, D. W. K. (1992). Further Evidence on the Great Crash, the Oil-Price Shock and the Unit-Root Hypothesis, Journal of Business \& Economic Statistics, 10 (3), 251-270.

\section{Internet Sources:}

www.worldometers.info

www.uk.finance.yahoo.com 